This is the author's final, peer-reviewed manuscript as accepted for publication. The publisher-formatted version may be available through the publisher's web site or your institution's library.

\title{
Regulating regulators in transitionally competitive markets
}

David E. M. Sappington and Dennis L. Weisman

\section{How to cite this manuscript}

If you make reference to this version of the manuscript, use the following information:

Sappington, D. E. M., \& Weisman, D. L. (2012). Regulating regulators in transitionally competitive markets. Retrieved from http://krex.ksu.edu

\section{Published Version Information}

Citation: Sappington, D. E. M., \& Weisman, D. L. (2012). Regulating regulators in transitionally competitive markets. Journal of Regulatory Economics, 41(1), 19-40.

Copyright: @ Springer Science+Business Media, LLC 2011

Digital Object Identifier (DOI): doi: 10.1007/s11149-011-9175-y

Publisher's Link: http://www.springerlink.com/content/j0k4002245535873/

This item was retrieved from the K-State Research Exchange (K-REx), the institutional repository of Kansas State University. K-REx is available at http://krex.ksu.edu 


\title{
Regulating Regulators in \\ Transitionally Competitive Markets
}

by

David E. M. Sappington* and Dennis L. Weisman**

\begin{abstract}
During the course of the first thirty CRRI conferences, we have gained considerable insight about how to design regulatory policy in the presence of developing competition. The insight to date has focused on how to harness competitive forces to motivate incumbent suppliers to serve the best interests of consumers. This paper stresses the importance of considering the incentives of regulators and explores the associated changes in standard recommendations for regulatory policy design in the presence of developing competition.
\end{abstract}

August 2011

* Department of Economics, University of Florida, Gainesville, FL 32611-7140 sapping@ufl.edu.

** Department of Economics, Kansas State University, Manhattan, KS 66506-4001 weisman@ksu.edu.

We thank Michael Crew, two anonymous referees, Glenn Robinson, and participants at CRRI's $30^{\text {th }}$ Annual Eastern Conference for helpful comments and observations. 


\section{Introduction.}

At the time of the inaugural Center for Research in Regulated Industries (CRRI) conference, the economics literature focused on the design of regulatory policy in monopoly settings. This focus reflected industry practice, as many key regulated sectors (including the energy, telecommunications, and water sectors) exhibited substantial elements of monopoly supply. Few residential customers had a choice among energy or water suppliers, and AT\&T was the dominant supplier of most telecommunications services.

Regulated industries have changed markedly in the last thirty years and the literature has changed accordingly. As competition developed in most regulated sectors, the literature explored how regulatory policy should change in the face of increasing competitive pressures. Price cap regulation, which affords incumbent suppliers expanded ability to compete with new industry suppliers, became a popular policy in practice and the subject of many scholarly studies (e.g. Crew and Kleindorfer 1996, 2002; Sappington, 2002; Vogelsang, 2002; Sappington and Weisman, 2010). The popularity of price cap regulation stems in part from its ability to adapt readily to changing industry conditions as competitive forces develop (e.g., Sappington and Weisman, 2010).

A substantial portion of the literature on regulation and competition analyzes how regulators can harness developing competitive forces to motivate incumbent suppliers to serve the best interests of consumers. In focusing on how to motivate incumbent suppliers, these studies often do not consider in detail the motivations of regulators. In practice, regulators do not always face ideal incentives to foster and manage industry competition appropriately. This is the case in part because competition can constrain a regulator's ability to implement policies that favor some constituents over others (Posner, 1971). For example, unfettered entry of new suppliers can limit a regulator's ability to set high prices for some services (e.g., long distance telephone service) in order to generate the revenue an incumbent supplier requires to finance particularly low prices for other services (e.g., basic local telephone service).

The incentives, mandates, and political pressures that regulators face imply that they may not be naturally inclined to follow standard prescriptions for the design of regulatory policy in the presence of developing competition. Therefore, some regulation of regulators may be appropriate. Although this observation and its implications have not been emphasized in the recent literature, the potential need to regulate regulators is well known. Indeed, in The Federalist No. 51, James Madison observes: 
But what is government itself but the greatest of all reflections on human nature? If men were angels, no government would be necessary. If angels were to govern men, neither external nor internal controls on government would be necessary. In framing a government which is to be administered by men over men, the great difficulty lies in this: you must first enable the government to control the governed; and in the next place oblige it to control itself (Hamilton, Jay and Madison, 1961, p. 322).

Because regulators may not be naturally inclined to follow standard prescriptions for modifying regulatory policy in the presence of developing competition, additional policies that complement judicial review in encouraging compliance with these prescriptions warrant consideration, as do refinements of the standard prescriptions. This paper reviews common recommendations for adapting regulatory policy as competitive forces strengthen. The paper also explains when and why regulators may be reluctant to follow these recommendations, and provides additional recommendations to counteract this reluctance. For instance, we recommend more widespread use of stringent sunset rules with accompanying oversight by antitrust authorities to counteract common regulatory reluctance to relax industry controls. We also recommend that policymakers err on the side of eliminating regulatory control too early rather than too late. ${ }^{1}$

The discussion proceeds as follows. Section 2 reviews the reasons why regulators may not always have ideal incentives to manage industry competition appropriately. Section 3 provides ten specific recommendations for how to structure industry policy in the presence of developing competition. Section 3 also identifies the elements of standard recommendations that regulators may be reluctant to follow, and suggests how to address this reluctance. Section 4 concludes with a discussion of some of the many difficult questions that remain to be answered when designing regulatory policy in the presence of developing competition.

\section{The Rationale for Regulating Regulators' Incentives.}

Regulators often implement policies that favor some constituents over others. To illustrate, regulators in the telecommunications industry set high prices for long distance telephone service in order to generate the revenues required to finance low prices for local service. Regulators also set identical prices for a service (e.g., local telephone service or first class mail service) throughout broad geographic regions despite large variation in the cost of

1 In this sense, the term "regulating regulators" may be somewhat of a misnomer. The regulation of regulators that we propose is better viewed as limiting or terminating key elements of regulatory control than as adding additional regulation in settings where regulation may already be excessive. 
providing the service. In the railroad industry, regulators implemented "value of service pricing" that required rail carriers to charge relatively low prices for transporting commodities with low retail value and relatively high prices for transporting goods with high retail value. ${ }^{2}$

In some instances, regulators are following the mandates of legislators when they implement policies (e.g., geographic averaging of prices) that benefit one set of constituents (e.g., local telephone customers who reside in remote areas that are relatively costly to serve) at the expense of other constituents (e.g., local telephone customers who live in densely populated regions that are less costly to serve). ${ }^{3}$ In other instances, regulators are responding to the demands of well organized, politically powerful constituents when they implement policies that favor these constituents (Stigler, 1971; Peltzman, 1976; Posner, 1975; McChesney, 1997). Whatever the impetus of policies that serve to redistribute surplus from less favored groups to more favored groups, regulators often continue to pursue the redistribution even when doing so limits the development of efficient competition. ${ }^{4}$

Competition can limit a regulator's ability to redistribute surplus from one group of constituents to another. For example, as non-incumbent suppliers of long distance telephone service secure expanded capacity and visibility, high prices for an incumbent supplier's long distance service may fail to generate substantial revenue that can be used to finance low prices for local telephone service. The high prices (and the associated cream-skimming behavior on the part of competitors that it encourages) may simply induce customers to seek alternative suppliers, and thereby reduce the incumbent supplier's revenues. Similarly, new suppliers of mail service may operate primarily on the routes that are least costly to serve and thereby limit the profit the incumbent supplier otherwise would earn on these routes. Furthermore, competing transporters of commodities with high retail value (e.g., truckers) can siphon off the revenue that value of service pricing would otherwise generate for incumbent rail carriers.

To protect revenue sources that finance valued redistribution, regulators can be tempted to limit the operations of competitors (Posner, 1971). Indeed, state regulators - those with direct

2 This mandate was intended in part to secure low transport prices for producers of agricultural products.

3 Section 254(3)(b) of the Telecommunications Act of 1996 states: "Consumers in all regions of the Nation, including low-income consumers and those in rural, insular, and high-cost areas, should have access to telecommunications and information services ... that are reasonably comparable to those services provided in urban regions and that are available at rates that are reasonably comparable to rates charged for similar services in urban areas.”

4 Efficient competition denotes competition that increases long term industry welfare. Inefficient competition is competition that reduces long term industry welfare. 
political accountability for rising local service rates - often opposed long distance competition on the grounds that such competition would erode subsidies to local service. ${ }^{5}$ Regulators also imposed cost-increasing restrictions on trucks to limit their ability to attract lucrative traffic from railroads. ${ }^{6}$ In addition, regulators implemented strict pricing, entry, and exit controls in the commercial airline industry that served to limit competition despite substantial evidence that the industry could support additional competitors (Levine, 1965, 1987). Corresponding controls have been imposed in the postal industry (Crew and Kleindorfer, 2011).

Regulators may also be tempted to limit industry competition because competition can introduce chaotic, unpredictable forces into the industry. In contrast, regulators are naturally inclined to favor stable, predictable industry performance, in part because they are held accountable for all problems that arise in the industry. Kahn (1984, p. 8) suggests there may be “... no rational half-way house between thorough regulation and free competition” in part because "the regulatory mentality is hostile to competition." In addition, regulation entails control, and a regulator that considers substituting competitive discipline for direct regulatory control is contemplating the unnatural and often disconcerting act of relinquishing control (Weisman and Robinson, 2009). Furthermore, diminished regulatory control can engender efforts to reduce regulatory resources, and regulators typically are averse to resource reductions (including the loss of jobs for valued staff members).

Even as regulators encounter incentives to discourage efficient competition in some settings, they may face incentives to encourage inefficient competition in other settings. For example, regulators may be inclined to demonstrate that they are fostering industry competition because competition is widely viewed as a source of lower prices and innovative services for consumers. Such demonstrations may involve documenting an increased number of industry competitors. However, long run industry welfare does not necessarily increase as the number of industry competitors increases. To illustrate, suppose a regulator requires an incumbent supplier

5 Brock (1994, Chapter 11) notes that state regulators and Congress both sought to block federal regulators from setting cost-based rates for interstate telephone service. Crandall and Waverman (1995, p. 85) estimate the annual welfare loss from inefficient pricing of telecommunications services in the U.S. to be $\$ 8$ billion annually. Some experts also suggest that the cost of regulatory delay associated with the introduction of cellular telephone service in the U.S. exceeded \$25 billion annually (Hausman, 1997).

6 Indeed, rather than emulate competitive discipline in the rail and truck industries, the Interstate Commerce Commission sought to cartelize the industries in order to avoid destructive price wars (Keeler, 1983; Baumol and Walton, 1973). The cartelization took the form of strict control over industry pricing and operating procedures. 
to make its network available for use by competing suppliers at non-compensatory prices. Such a policy can increase the number of competitors in the short run. However, it can also discourage the incumbent supplier from maintaining, expanding, and enhancing its network. The policy also can limit the incentives of competitors to build their own networks. Both effects can reduce long term industry welfare. ${ }^{7}$

Regulators may also be tempted to foster inefficient competition in some settings in order to transfer to favored constituents surplus that would otherwise accrue to the incumbent supplier. To illustrate, consider a setting where the incumbent supplier operates under a price cap regulation plan that severs the link between the supplier's earnings and the rate at which it can increase the prices of its retail services. Under such a plan, the regulator is not obligated to alter the prevailing pricing rules even if the incumbent supplier's earnings fall far below expected levels. Consequently, a regulator might be tempted to facilitate competitive entry that reduces prices for certain services, knowing that she will not have to authorize higher prices for other services in order to ensure reasonable earnings for the incumbent supplier. ${ }^{8}$

For all these reasons, regulators may not always be inclined to promote efficient competition and limit inefficient competition appropriately. Consequently, policies that alter imperfect regulatory incentives or counter the undesirable effects of these incentives merit consideration. We suggest some such policies in section 3 in the course of reviewing standard recommendations for the design of regulatory policy in the presence of developing competition.

\section{Recommendations for Regulating Regulators.}

We now present ten specific recommendations for adapting regulatory policy in the presence of developing competition. Many of these recommendations (e.g., Recommendations 1, 3, 4, and 10) reflect well-known principles. Others (e.g., Recommendations 2, 6, 7, 8, and 9) include some new suggestions. In reviewing these recommendations, we identify elements that regulators may be reluctant to follow. We also offer recommendations that may help to counteract regulatory reluctance to foster efficient competition and discourage inefficient competition.

7 Some studies present evidence of such discouragement in the telecommunications industry in recent years (e.g., Grajek and Röller, 2011). Ginsburg (2009, p. 5) discusses some of the problems that arise from "synthetic competition," which occurs "in a market subject to a regulatory regime designed to assure there are multiple sellers regardless of whether fewer firms ... would be more efficient."

8 See Lehman and Weisman (2000a,b) for further discussion of such behavior and evidence that the behavior may have occurred in the telecommunications industry in recent years. 
Recommendation 1. Set prices to reflect efficient, realized production costs.

As competition develops in an industry, the prices a regulated incumbent supplier charges should reflect its production costs. Otherwise, industry costs can rise as efficient competitors are excluded from the industry and inefficient competitors are allowed to prosper in the industry. ${ }^{9}$

When an incumbent supplier's price for a service is less than its unit cost of production, a more efficient competitor may be unable to operate profitably in the industry. Conversely, if an incumbent supplier is required to maintain a price that exceeds its unit cost of production, a less efficient competitor can set a lower price and thereby attract consumers. In both cases, prices that diverge from cost can increase industry operating costs and undermine the natural competitive forces that promote the operation of the least-cost industry suppliers. ${ }^{10}$

For the reasons identified in section 2, regulators may not always be inclined to implement prices that reflect the costs of the incumbent supplier. ${ }^{11}$ However, regulators can be encouraged to do so. For instance, the benefits that regulators often feel compelled to deliver to favored constituents through the regulated price structure might be delivered in alternative ways. For example, subsidies might be provided to low-income individuals who purchase regulated service in regions where the service is particularly costly to deliver. These subsidies could be financed either by general tax revenues or by a competitively neutral tax on all industry suppliers. Such a tax helps to minimize industry costs by ensuring that inefficient suppliers do not prevail in the market simply because they are not obligated to pay a tax that the incumbent supplier must pay. ${ }^{12}$

Recommendation 2. Employ competitive discipline to complement, substitute for, and/or inform regulatory discipline.

9 Armstrong and Sappington (2006) offer a corresponding recommendation. The authors also endorse the central elements of recommendations 3, 4, and 10 below.

10 As Baumol and Sidak (1994, p. 37) observe, the prices generated by market forces, in contrast to regulated prices, often approximate Ramsey prices.

11 Crandall (1989, p. 122) notes that regulators may not be alone in their desire to set prices that diverge from production costs. He suggests that AT\&T may have tolerated ongoing subsidies from long distance telephone service to basic local service in order to garner strong allies - state regulators - in opposing competitive entry into long-distance markets.

12 See Armstrong (2001, 2002), for example, for further discussion of this issue. 
The stringency and structure of regulatory policy should be adapted to reflect the strength and nature of the prevailing competitive discipline. To illustrate this more general principle, consider the appropriate design of price cap regulation.

Price cap regulation specifies the rate at which the incumbent supplier's inflationadjusted prices can increase, on average. The essence of price cap regulation is to choose an appropriate rate of authorized price increase. A rate that is too high can harm consumers by permitting supra-competitive prices. A rate that is too low can jeopardize the financial integrity of the regulated supplier and thereby reduce the intensity of industry competition and limit the ability of the incumbent supplier to serve its customers' needs.

Unavoidably imperfect information makes it virtually impossible for regulators to identify precisely the ideal rate of authorized price increase. Developing competition, though, reduces the likely harm from setting relatively lenient price controls. An incumbent supplier that increases prices substantially above cost in response to relaxed regulatory mandates emboldens potential and actual competitors by affording them expanded opportunity for profitable operation. Consequently, the incumbent supplier may choose not to take full advantage of authorized price increases, which limits the short term harm from lenient price controls. Furthermore, the long term harm from lenient price controls is diminished by the increased competition that short term price increases engender.

Furthermore, overly stringent price controls can stifle competition by limiting the opportunity for profitable industry operation. Therefore, as competition intensifies in an industry, less stringent explicit price controls generally are advisable. ${ }^{13}$ Regulators in the United Kingdom appeared to acknowledge these considerations in 2003 when, rather than continuing to mandate reductions in the average price charged by British Telecom, they simply required no increase in the average price. The regulators noted that "such a safeguard control reduces the risk of distortion of competition” (OFTEL, 2003, ๆ 6.17). ${ }^{14}$

13 Robinson and Weisman (2008, pp. 534-540) observe that because regulators typically have relatively short tenures and because prices are more readily measured than is innovation, some regulators may be inclined to emphasize short term price reductions over long term innovation.

14 Because consumers and elected officials often are concerned primarily with short term benefits and costs, regulators may face severe criticism if they implement policies that impose short term costs (e.g., current high prices) in order to secure long term benefits (e.g., future low prices and product innovation). To limit such criticism, regulators can publicly embrace the many long term benefits that arise when current regulatory policies stimulate efficient long term competition. As The 1996 Telecommunications Act (Preamble and Section 706) and Colorado Revised Statutes (2008, Section 40-15-501) emphasize, these benefits can include reduced regulation, lower prices, increased product quality and variety, and enhanced investment in modern industry infrastructure. Regulators also may 
Competitive forces often develop at different rates in different market segments. When they do, regulations can and should be modified to limit regulatory protection to where it is needed. For example, price controls might be imposed only in geographic regions where competitive discipline is limited. In addition, regulations might be focused on the wholesale sector of an industry where competition is limited, and largely removed from the retail sector if actual or potential competition prevails there. Furthermore, regulatory protection might be focused on consumers with limited income in settings where competitors offer high quality substitutes for a regulated service at prices that exceed the price of the regulated service. More targeted regulation can best serve consumers by reducing the costs of regulation and by limiting distortions of the competitive process.

Uneven development of competitive forces also can allow regulators to employ market outcomes in regions with stronger competitive pressure to inform the design of regulatory policy in regions with less pronounced competitive pressure. To illustrate, suppose production costs are known to be similar throughout a geographic area that is comprised of regions A and B. Further suppose that competition is substantially more developed in region A than in region B. A regulatory policy that requires identical prices in regions $\mathrm{A}$ and $\mathrm{B}$ without explicitly mandating particular price levels can import into region $B$ the disciplinary benefits of competition in region A. ${ }^{15}$

Corresponding benefits can be secured in settings where a regulator is well informed about the prevailing differences in production costs across regions $\mathrm{A}$ and $\mathrm{B}$, but knows relatively little about the prevailing cost levels. To illustrate, if unit production costs are known to be $20 \%$ higher in region $\mathrm{B}$ than in region $\mathrm{A}$, the regulator can restrict prices in region $\mathrm{B}$ to be no more than $120 \%$ of the prices in region $\mathrm{A}$.

In practice, the information required to import the full intensity of competition from one region to another typically will not be available. ${ }^{16,17}$ However, regulators often can glean from

be well served by documenting the benefits that efforts to stimulate efficient long term competition (and innovation) have produced in other jurisdictions.

15 When it eliminated most retail price controls in the U.K. in 2006, OFCOM (2006, section 5.9) required British Telecom to "price its narrowband services on a uniform basis, irrespective of geographic location.”

16 Prevailing prices typically reflect both demand and cost considerations. In principle, cross-region price differentials could be specified that reflect relevant differences in both costs and demand (Hausman and Sidak, 2007). In practice, though, the relevant calculations can be complex and can require considerable information that often is not readily available to regulators. 
observing outcomes in more competitive regions useful information about the outcomes that might reasonably be achieved in less competitive regions.

Recommendation 3. Limit under-funded asymmetric obligations on incumbent suppliers.

Regulators typically decline to impose on non-incumbent suppliers the same restrictions they impose on incumbent suppliers. A desire to avoid expanding the boundaries of regulatory control is commendable. However, regulators should seek to ensure that any asymmetric application of rules and regulations serves the long term interests of consumers.

To illustrate, consider the asymmetric imposition of a carrier-of-last-resort (COLR) obligation on an incumbent supplier. ${ }^{18}$ It is costly for a supplier to stand ready to provide service to any customer that might ultimately choose to purchase the service. Therefore, in the absence of any direct compensation for assuming the COLR obligation, the incumbent supplier will need to set its prices to recover these costs. A competing supplier that faces no COLR obligation does not incur the associated costs, and so can profitably charge lower prices than the incumbent supplier. In such a case, the competitor may be able to prevail in the marketplace not because it is the more efficient or the more innovative supplier, but simply because a COLR obligation has been imposed asymmetrically on the incumbent supplier (Kahn, 1971, p. 238). ${ }^{19}$

This simple example illustrates the more general principle that as competition develops in an industry, it is important to continually review the obligations that have been imposed on incumbent suppliers. Obligations that do not clearly deliver benefits to consumers in excess of the corresponding costs should be eliminated or revised appropriately. A corollary of this principle is that the preferred means to avoid undesirable asymmetric obligations on different industry suppliers often is to reduce the obligation on the incumbent supplier rather than extend the obligation to non-incumbent suppliers.

17 Furthermore, a mandate to set the same or a similar price in different regions can reduce the intensity of competition in the more competitive region. A supplier will be reluctant to reduce the price it charges in the more competitive regions when it knows that this price reduction will obligate it to reduce the price it charges in the less competitive region. See DeGraba (1987).

18 A supplier with a carrier-of-last-resort obligation must provide a designated service at a specified price to any customer that requests the service, regardless of the magnitude of the financial loss the supplier might incur in providing the service (Weisman, 1988).

19 A delicate balancing of consumers' needs to be served and suppliers' obligations to serve is required to ensure the ongoing attraction of essential industry investment. Competition and an asymmetric COLR obligation can upset this balance and thereby jeopardize industry investment (Posner, 1971; Goldberg, 1976; de Butts, 1973). 
In settings where a COLR obligation is deemed to be essential, all suppliers might be invited to bid for the right to serve as the COLR supplier. The winning bidder would be the supplier that agrees to assume the obligation in return for the least compensation. The compensation delivered to the winning bidder might be financed by a symmetric tax placed on all industry suppliers.

Limiting under-funded asymmetric obligations on industry suppliers can be viewed as one form of "leveling the playing field" for industry suppliers. It is important to note in this regard that the playing field should be leveled ex ante to ensure an equal opportunity for all industry suppliers to compete on the merits. The playing field should not be leveled ex post to ensure that industry participants secure comparable returns. ${ }^{20}$ Nor should the field be adjusted to provide efficient and inefficient suppliers with the same prospects of succeeding in the marketplace. ${ }^{21}$ Attempts to handicap winners and subsidize losers in the competitive process can dull incentives for superior performance, to the long term detriment of consumers.

Recommendation 4. Empower consumers to discipline industry suppliers.

When they operate in settings with developing competition, regulators can enlist the aid of consumers in imposing discipline on incumbent suppliers. Regulators can do so by making relevant information readily available to consumers and by limiting impediments to use of this information.

Consumers discipline suppliers by awarding their patronage to the supplier that best serves their needs. For this form of discipline to be effective, consumers must be well aware of the set of suppliers that could conceivably serve their needs, the services these suppliers offer, and the terms and conditions on which the services are supplied. Regulators can help to disseminate this information in settings where consumers do not readily access the information on their own, perhaps simply because they are unaccustomed to having a choice among suppliers

20 Kahn (1984, p. 9) observes that "The regulator tends as a matter of constitutional preference ... to convert the maintaining of the 'level playing fields' into an interference with the contest itself. Regulators move from trying to assure a fair and equal start to ensuring an equal finish; to preserve whatever the regulator conceives to be the proper market shares of the various competitors."

21 The Antitrust Modernization Commission (2007, p. 34) observes that “... the Supreme Court in 1977 stated without caveat that "the antitrust laws ... were enacted for the 'protection of competition, not competitors.' ... [T]rade-offs exist between the goals of consumer welfare and protecting small firms. To protect small firms can mean a less efficient economy in which consumers must pay higher prices (footnotes omitted).” 
of the regulated service. Regulators might assemble the relevant information on their websites, for example, and require incumbent suppliers to report the address for the website on the bills they send to customers.

Performance information also can help consumers choose among potential suppliers. In settings where regulators collect price and quality information, they can make this information available to consumers. Of course, many consumers find it difficult to devote the time required to review relevant performance data carefully, and some consumers can find such reviews to be challenging. Consequently, it is important to present relevant data in a readily accessible format. $^{22}$ When possible, regulators also should avoid emphasizing unduly a few limited dimensions of performance. Such emphasis can induce suppliers to focus their efforts on improving the most emphasized performance dimensions while devoting relatively little effort to less emphasized dimensions. In settings where regulators do not collect performance data, they can direct consumers to independent organizations that collect the data. Regulators might also support customer blogs that allow consumers to describe their experiences with industry suppliers.

Regulators also can help empower consumers to discipline incumbent (and nonincumbent) suppliers by limiting customer impediments to switching suppliers. To illustrate, number portability requirements that enable a consumer to maintain her same telephone number if she switches to a new supplier of telephone service decreases the inconvenience associated with switching suppliers. As the cost of switching suppliers declines, consumers become more likely to switch to a new supplier when they become dissatisfied with the performance of their present supplier. The threat of losing customers can impose substantial discipline on all industry suppliers, given the relatively high costs of attracting new (and former) customers. ${ }^{23}$

Recommendation 5. Foster enduring, effective competition.

22 The U.S. Federal Communications Commission (FCC, 2009, ๆ 5) emphasizes "the importance of identifying [information] disclosure policies that have a high ratio of consumer benefit to industry cost. If designed correctly, disclosure policies are among the least intrusive regulatory measures at the Commission's disposal. Moreover, access to accurate information plays a central role in maintaining a well-functioning marketplace that encourages competition, innovation, low prices, and high-quality services" (footnotes omitted).

23 To ensure that consumers base their choice of supplier on the relative performance of suppliers in the marketplace, regulators should not provide artificial inducements for customers to leave the incumbent provider for a rival (Kahn, 1999). 
Regulators may have some choice regarding the type of competition they foster. In the telecommunications industry, for example, regulators can encourage the operation of retail suppliers that do little more than re-sell the services of facilities-based incumbent suppliers. ${ }^{24}$ Alternatively, regulators can encourage the operation of new facilities-based suppliers of telecommunications services. Non-facilities-based competition is encouraged when incumbent suppliers are required to make their networks available for use by retail competitors on terms that are particularly favorable to the competitors. Terms that are less attractive to competitors (i.e., higher access charges) and more limited mandates to make network elements available to competitors can encourage non-incumbent suppliers to invest in their own facilities. Competition among independent facilities-based suppliers can generate innovative services and provide strong incentives to deliver these services at low cost. ${ }^{25}$ Consequently, even though relatively high access charges may limit competitive pressures from non-facilities-based suppliers in the short run, the high charges can enhance the prospects for intense facilities-based competition in the long run (Grajek and Röller, 2011; Hazlett, 2006; Hazlett and Caliskan, 2008). ${ }^{26}$ Such competition can reduce the need for enduring industry regulation. ${ }^{27}$

In settings where a loyal customer base substantially reduces the financial risk associated with investing in network facilities, access charges that increase over time may facilitate a transition to robust facilities-based competition. New industry suppliers can initially employ the incumbent's network at relatively low cost to attract a customer base. The new suppliers can subsequently construct and employ their own networks to serve customers rather than pay increasing access charges to incumbent suppliers (Avenali et al., 2010). ${ }^{28}$

${ }^{24}$ Gifford (2003) suggests that regulators may encourage such competition in part to bolster the case that they have successfully fostered robust industry competition.

25 The U.S. Federal Communications and the Canadian Radio-television and Telecommunications Commission have both expressed a preference for facilities-based competition rather than competition that relies upon resale or unbundled network elements. See FCC (2005, ๆף 2, 33, 218, and note 594) and CRTC (1997, ๆ 73).

26 Cambini and Jiang (2009) review recent studies of the impact of regulatory policy on broadband infrastructure investment.

27 Consequently, fostering such competition is consistent with the call to "reduce regulation" (Preamble, 1996 Telecommunications Act of 1996. Pub. L. No. 104-104, 110 Stat. 56 (codified as amended in scattered sections of 47 U.S.C.)).

28 Regulators may face criticism if some non-facilities-based suppliers fail as access charges rise (Robinson and Weisman, 2008). However, such failure could reflect the shortcomings of suppliers rather than flawed regulatory policy. The non-facilities-based suppliers that fail may predominantly be firms that are unable to convince capital markets to fund their business plans. 
Recommendation 6. Implement standards that foster, but do not abuse, competitive discipline.

The vibrant and often unpredictable nature of competition can produce substantial volatility in the earnings of industry participants. Regulated incumbent suppliers should not be insulated from the increased earnings risk that competition can introduce. Such insulation would dull the incumbent supplier's incentive to compete vigorously against industry rivals, and thereby harm consumers. On the other hand, market competition should not be artificially propagated so as to expropriate the incumbent supplier.

To illustrate this more general conclusion, consider a setting where the incumbent supplier operates under price cap regulation that divorces the rate at which its prices can increase from its realized costs and earnings. Such a plan can provide strong incentives for the incumbent supplier to operate efficiently. However, as noted in section 2, it can also create incentives for regulators to disadvantage the incumbent supplier, in part by implementing rules that unduly favor non-incumbent suppliers. For example, the regulator might obligate the incumbent supplier to provide retail competitors with access to its network on terms and conditions that are very favorable to the competitors. Alternatively, the regulator might saddle the incumbent supplier asymmetrically with costly carrier-of-last-resort obligations or mandates to deliver levels of service quality in excess of surplus-maximizing levels. Such policies can effectively enable regulators to deliver benefits to consumers without obligating consumers to bear the associated costs.

An incumbent supplier's ability to attract the capital required for ongoing operation can be seriously impeded by regulatory policies that provide substantial advantages to competitors at the expense of incumbent suppliers. Therefore, it is appropriate to limit the incidence of such policies without unduly impeding the regulator's ability to implement desirable industry policy. One way to do so may be to adopt a standard for appropriate regulatory policy that explicitly recognizes and discourages actions that advantage competitors in such a way as to expropriate incumbent suppliers. ${ }^{29}$ For example, the Hope standard might be explicitly augmented to limit

29 In principle, incentives for regulatory expropriation can be limited by replacing price cap regulation with earnings sharing regulation (ESR). ESR generally insures an incumbent supplier against particularly low earnings, and so regulatory policies that produce low earnings for the incumbent supplier become costly for the regulator. In practice, though, regulators typically have some discretion in how earnings are measured. Consequently, ESR may fail to provide the incumbent supplier with substantial protection against expropriation, even as it dulls the incumbent's incentives for superior performance in the marketplace. An obligation to share revenues, rather than earnings, may provide some protection against such expropriation (Sappington and Weisman, 1996b). 
regulatory takings, ${ }^{30}$ as in the Market Street Railway decision. The Hope standard, which is generally recognized as the litmus test for whether a firm that operates under rate of return regulation has been afforded adequate revenue, indicates that the regulated firm is entitled to a "return ... sufficient to assure confidence in the financial integrity of the enterprise, so as to maintain its credit and attract capital." ${ }^{11}$ The Market Street Railway decision indicates that while the due process clause of the Fourteenth Amendment cannot be applied to "insure values or restore values that have been lost by the operation of economic forces," the clause does protect utilities against "governmental destruction of existing economic values."32

In practice, it is difficult to distinguish precisely between the natural operation of competitive forces and unnatural propagation of these forces that expropriate incumbent suppliers. Therefore, undesirable regulatory expropriation may be difficult to identify and preclude. However, explicit recognition of the fact that excessive advantaging of competitors can serve to expropriate incumbent suppliers and explicit directives to avoid such expropriation may help to limit its incidence. ${ }^{33}$

Recommendation 7. Continuously assess where ongoing regulation is essential, eliminate regulation where it is not essential, and employ stringent sunset provisions with antitrust oversight where appropriate.

It is imperative that regulators constantly gather the data required to make an informed assessment of the extent to which regulatory controls can be altered or relaxed. Data on the capacities and the potential service areas of all industry competitors can be of particular value in

30 A "taking” can be viewed as a confiscation of property without adequate compensation. See Sidak and Spulber (1997) and Weisman (2002).

31 See Federal Power Commission vs. Hope Natural Gas Co. (1944).

32 Market Street Railway Co. v. Railroad Commission of California (1945). In Duquesne Light Co. vs. Barasch (1989), the Supreme Court ruled that a regulator need not permit an incumbent supplier to recover an investment that was prudent at the time it was made but is no longer used and useful due to unforeseen consequences. The Court observed that such investments would not be recoverable in a competitive market. An important question is whether Duquesne should apply if the prudent investment is no longer used and useful primarily because of regulatory policies that are excessively advantageous to competitors of the incumbent supplier.

33 Under the Hope standard, a regulatory policy that advantages rivals and disadvantages the incumbent does not constitute a taking as long as the incumbent supplier's earnings are adequate. (See Verizon Communications Inc. vs. FCC, 2002.) Such a standard admits a serious incentive problem because the more efficient and innovative is the incumbent supplier, the greater are its earnings and thus the greater is the regulator's discretion to expropriate the incumbent and advantage its rivals. 
this regard. Regulators may need to keep this data confidential in order to prevent undesired disclosure of proprietary information. However, regulators must have this data in order to determine the extent to which competitive discipline can substitute for direct regulatory control.

Coordination among regulators would be particularly useful in this regard to ensure that all regulators have ongoing access to consistent, comprehensive, and current data. A data set that records regulatory decisions and industry performance across a broad set of regulatory jurisdictions would help regulators determine when market forces are sufficient to protect consumers adequately and to assess the types of regulatory control that best protect consumers when such protection is warranted.

Even when the relevant data are available, it is difficult to assess precisely when and how regulatory policies should be modified to reflect developing competition. In the face of uncertainty about the most appropriate policy changes, the easiest change to implement often is no change at all. Sunset provisions can be employed to limit inertia that would otherwise keep rules and regulations in place beyond their useful life. Sunset provisions can specify that substantial regulatory change (e.g., forbearance or even complete deregulation) will be implemented at a specified date unless convincing evidence is presented to justify the ongoing need for the prevailing regulations. By clearly indicating the intended transitory nature of regulations, sunset provisions can help to avoid the natural, but often inappropriate, presumption that regulations are an inevitable and enduring feature of the industry landscape. Sunset provisions also shift the burden of proof from the advocates of change (who must otherwise prove that substantial regulatory change is appropriate) to regulators, who must now demonstrate why change is not appropriate..$^{34,35}$

The demonstrations mandated by sunset provisions generally should be overseen by an entity other than the regulator. Otherwise, the regulator would effectively act as both the key litigant and the judge in the proceeding. The required oversight might be provided by the relevant federal antitrust authority, for example. Oversight by federal antitrust agencies can be particularly appropriate because of the typical experience, skills, and focus of these agencies. Antitrust authorities often have considerable expertise both in assessing whether industry suppliers have substantial market power and in identifying the sources of such power.

34 To help encourage efficient competition, the Canadian government dictated specific criteria that regulators must employ to determine when forbearance from regulation is warranted (Industry Canada, 2007). Brennan (2008) provides a useful account and assessment of related developments.

35 By requiring regulators to continually justify their policies, sunset provisions also can help to limit undesirable regulatory expropriation. 
Determining the nature and the strength of prevailing market power is the key issue in assessing whether a substantial reduction in regulatory oversight is appropriate. Furthermore, in contrast to regulators, antitrust agencies typically oversee activities in a broad array of industries. Consequently, antitrust agencies tend to be less susceptible to capture by powerful constituents in a regulated industry. Their reduced risk of capture, along with their experience, skills, and focus tend to make federal antitrust agencies particularly capable overseers of sunset provisions. ${ }^{36}$

When they decide whether ongoing regulation or deregulation is more appropriate, antitrust authorities are more likely to base their decision on which option is likely to ensure a higher level of long term industry welfare. ${ }^{37}$ Anticipating such a decision on the part of antitrust authorities, regulators who favor ongoing regulatory control will be reluctant to undertake policies that reduce long term welfare by impeding efficient competition. Such policies will only encourage antitrust authorities to mandate industry deregulation. Therefore, the prospect of antitrust oversight can encourage regulation that promotes efficient competition.

Courts presently provide the primary oversight of regulatory decisions. This oversight is limited, though, because courts typically defer to regulators on key substantive issues. Courts tend to remand or vacate regulatory decisions only if regulators have clearly violated required procedures or prescribed mandates. As the U.S. Supreme Court has observed, the primary "job of judges is to ask whether [a regulator] made choices reasonably within the pale of statutory possibility, ${ }^{38}$ not whether the choices promote efficient industry competition. ${ }^{39}$ While courts can

36 Antitrust influence in regulatory proceedings has precedence. To illustrate, the U.S. Department of Justice commissioned a study of the merits of the line-of-business restrictions on the Bell Operating Companies (Huber, 1987). Furthermore, Section 271(d)(2)(a) of the 1996 Telecommunications Act requires the Justice Department to be consulted on the advisability of allowing the Bell Companies to enter the interLATA long-distance market. In Canada, the Competition Bureau has played a prominent role in essential facilities cases and regulatory forbearance matters in the telecommunications industry. See, for example, CRTC (2005, 2007a,b).

37 To illustrate, in assessing potential regulatory policy in broadband markets, the U.S. Department of Justice advised the FCC to "monitor carefully those areas in which only a single provider offers - or even two providers offer - broadband service. Although enacting some form of regulation to prevent certain providers from exercising market power may be tempting with regard to such areas, care must be taken to avoid stifling the infrastructure investments needed to expand broadband access. In particular, price regulation would be appropriate only where necessary to protect consumers from the exercise of monopoly power and where such regulation would not stifle incentives to invest in infrastructure deployment” (USDOJ, 2010, p. 28).

38 Verizon Communications Inc. v. FCC, 2002, at 539.

39 In his dissenting opinion in Verizon, Justice Breyer observes that "As a reviewing Court, we must determine ... whether the Commission has 'abuse[d]' its statutorily delegated 'discretion' to create implementing rules. ... In doing so, we must assume that Congress intended to grant the Commission 
continue to employ their legal expertise to help ensure that regulators act in a manner that is broadly consistent with their mandates, antitrust agencies can employ their expertise in matters relating to market power and industry competition to assess whether regulatory rulings promote efficient industry competition and discourage inefficient competition.

Of course, antitrust authorities, like regulators, typically will be obligated to follow legislative mandates. Consequently, antitrust authorities will not have unmitigated discretion to terminate legislated benefits for certain groups of customers or ignore legislative mandates that inhibit efficient competition or promote inefficient competition. However, legislation typically provides considerable discretion in how broad mandates are achieved, and antitrust authorities often are well situated to help ensure that specified legislative mandates are fulfilled with the smallest possible loss of industry surplus. ${ }^{40}$

Antitrust authorities, like regulators, will not be immune to political pressure (McChesney and Shughart, 1995). However, federal antitrust authorities may be somewhat insulated from local political pressure. Furthermore, requiring antitrust authorities to oversee preordained sunset proceedings at specified time intervals can limit the discretion of antitrust officials regarding the cases they will pursue. This reduced discretion can help render antitrust authorities less vulnerable to political pressure.

Recommendation 8. Err on the side of eliminating regulatory controls too early rather than too late.

It can be difficult in practice to determine precisely when substantial regulatory change such as forbearance or deregulation is warranted. If a substantial reduction in regulatory control is implemented before competition has developed to the point where it can discipline incumbent suppliers adequately (i.e., if “early deregulation” occurs), consumers may face higher prices

broad legal leeway in respect to the substantive content of the rules” (Verizon Communications Inc. v. FCC, 2002, at 541-42). Similarly, the Supreme Court notes that "When a challenge to agency construction of a statutory provision, fairly conceptualized, really centers on the wisdom of the agency's policy, rather than whether it is a reasonable choice within a gap left open by Congress, the challenge must fail. In such a case, federal judges - who have no constituency - have a duty to respect legitimate policy choices by those who do" (Chevron U.S.A., Inc. v. Natural Resources Defense Council, Inc., 1984, at 866).

40 For example, in settings where ongoing government intervention is deemed to be warranted to foster universal service, antitrust authorities might insist that all industry participants contribute to a universal service fund in a competitively neutral manner rather than impose (under-funded) obligations asymmetrically on incumbent suppliers. See Recommendation 3. 
and/or reduced service quality. Different inefficiencies can emerge if regulatory control persists beyond the point at which competition alone can discipline all industry suppliers adequately (i.e., if "late deregulation" occurs). One such inefficiency is the reduced intensity of industry competition that typically arises when potential suppliers of new products and services decline to enter the industry because the incumbent's artificially low prices render such entry unprofitable. Another inefficiency arises from the higher industry costs resulting from the fact that inefficient entrants may be able to operate profitably simply because they do not face the same restrictions that incumbent suppliers face.

The practical difficulties associated with determining precisely when deregulation (or, more generally, a substantial reduction in regulatory control) is appropriate place regulators in the unenviable position of choosing between deregulation that is likely to be either too early or too late. Faced with this choice, erring on the side of early deregulation often is advisable. ${ }^{41}$ This is the case in part because the problems associated with early deregulation are more amenable to self-correction than are the problems caused by late deregulation.

To explain this asymmetry, suppose early deregulation permits the incumbent supplier to set prices substantially above cost and the incumbent chooses to do so. The resulting increased opportunity to secure profit will stimulate increased entry by efficient suppliers. ${ }^{42}$ Similarly, if relaxed service quality regulation leads the incumbent supplier to reduce the quality it delivers to its customers below surplus-maximizing levels, the customers will intensify their search for alternative suppliers who offer a preferred combination of quality and price.

In contrast, the problems associated with late deregulation typically are not selfcorrecting. To illustrate, regulated prices set below the incumbent supplier's unit cost of production typically allow little or no opportunity for profitable operation by non-incumbent suppliers. In addition, outdated mandates to provide levels of service quality in excess of the levels that consumers wish to purchase can limit an incumbent supplier's ability to attract and

41 When antitrust authorities have the power to determine when deregulation is appropriate, deregulation will tend to be implemented sooner if the prevailing regulatory policy discourages efficient entry. In such a case, antitrust authorities are relatively likely to conclude that even imperfect competition is superior to the prevailing imperfect regulation.

42 The entry will be more pronounced if potential competitors believe the incumbent's high prices will persist. Conceivably, incumbent suppliers might be required to maintain any price increases they implement for some specified period of time. This requirement could limit the attraction of, and thereby deter, some price increases. This possibility parallels Baumol's (1979) suggestion for discouraging predatory pricing, namely to require firms to maintain below-cost prices after competitors leave the industry in response to the low prices. 
retain customers. In these instances and others, inappropriate regulatory mandates can limit the ability of market forces to ensure that the most efficient suppliers deliver to consumers surplusmaximizing combinations of prices and qualities. ${ }^{43}$

To guard against late deregulation, regulators should not wait until competitors have developed perfect substitutes for the incumbent supplier's services before initiating substantial deregulation of the incumbent's services. To illustrate, suppliers of wireless telephone service can impose substantial discipline on suppliers of wireline telephone service even if most consumers perceive the quality of wireline calls to exceed the quality of wireless calls. Suppliers of imperfect substitutes can deliver particularly strong discipline when the price of a service is substantially above its avoidable cost of production. ${ }^{44}$

Stringent sunset requirements (overseen by antitrust officials) can be a particularly effective means to avoid undue delays in deregulation. When regulators and/or other interested parties are required to present very compelling evidence of the need for ongoing regulation in order to secure such regulation, deregulation is more likely to be implemented in a timely manner. Sunset requirements overseen by an antitrust authority also can help to shield regulators from unjustified criticism that they relaxed industry controls prematurely, and can thereby encourage timely deregulation.

Recommendation 9. Coordinate regulatory and legislative policies and mandates to limit both intentional and unintentional roadblocks to efficient competition.

Policymakers and regulators should coordinate their policies and speak with one voice when articulating industry rules and regulations. Otherwise, industry suppliers will face unnecessary uncertainty about the likely returns from their industry investment, and so may curtail welfare-enhancing investment. Furthermore, regulators may face the added burden of having to overcome the actions of other regulators or policymakers that impede efficient competition.

43 As Judge Easterbrook (1984, p. 15) observes, “[T]he economic system corrects monopoly more readily than it corrects [regulatory] errors. ... [I]n many cases, the costs of monopoly wrongly permitted are small, while the costs of competition wrongly condemned are large.”

44 Regulated firms often incur large fixed costs of production and relatively small marginal costs of production. Consequently, regulated prices that allow a normal return on investment often will be well above marginal production costs. Such high price-cost margins imply that a regulated firm incurs a substantial reduction in profit if it loses customers to competitors, and so the firm will compete vigorously to maintain customer loyalty as competition develops. See Hausman (2003) and Weisman (2006). 
The U.S. Federal Communications Commission (FCC) faced this burden when it attempted to lower the prices of long distance telephone and network access services toward cost. Although the price reductions would have increased industry surplus substantially, they would have required sizable increases in the price of basic telephone service. Consequently, the U.S. Congress and state regulators (who would have borne the brunt of consumer opposition to these price increases) opposed the FCC's proposed policy. Their opposition compelled the FCC to slow its intended pace of rate reform (Brock, 1994, chapter 11). ${ }^{45}$

In 1996, the U.S. Congress acted to preempt regulatory and legislative interference with its efforts to open the telecommunications industry to widespread competition. The Telecommunications Act explicitly prohibited state and local regulators and policymakers from limiting entry into the industry. ${ }^{46}$ Explicit prohibitions of this sort can promote consistent industry policy. Collaboration in crafting industry regulation and legislation can also produce consistent, coherent industry policy and thereby foster efficient competition, facilitate long-term planning, and encourage industry investment.

Recommendation 10. At the appropriate time, transfer industry oversight from regulators to antitrust officials.

Detailed ex ante regulation is appropriate in settings where it is highly likely that competitive forces alone will be insufficient to protect consumers adequately. In such settings, well designed rules and regulations can deliver the consumer protection that market competition alone is unlikely to provide. Selective ex post antitrust intervention is more appropriate than regulation when competitive forces are likely, albeit not certain, to protect consumers adequately. In such settings, antitrust review can provide a useful check on market performance without unduly influencing the nature and direction of market competition. ${ }^{47}$

Selective antitrust scrutiny offers at least three advantages over pervasive regulation. First, selective ex post intervention generally is less costly to implement. Second, antitrust oversight is less prone to error than is regulation in settings with developing competition. The

45 Keeler (1983, Chapter 5) describes a similar conflict in the railroad industry that pitted new legislation against the enforcement of that legislation by the Interstate Commerce Commission.

46 Section 253(a) of the Act states: "No State or local statute or regulation, or other State or local legal requirement, may prohibit or have the effect of prohibiting the ability of any entity to provide any interstate or intrastate telecommunications service.”

47 Tardiff and Taylor (2003, p. 345) describe the transition from stringent regulatory control to unfettered market competition. 
vibrant, often unpredictable nature of competition makes it difficult to devise rules that will foster rather than retard competitive forces and that will be appropriate for the market conditions that ultimately evolve. Consequently, it can be preferable to monitor the conditions that evolve and correct any observed imperfections that limit the market's ability to serve the best interests of consumers.

Third, antitrust is less subject to capture than is regulation (Baker, 2003). Frequent, ongoing interactions between regulators and regulated entities facilitate regulatory capture by powerful constituents (Stigler, 1971). Such capture limits the likelihood that industry rules will best serve the combined interests of all industry participants.

Because antitrust review can provide valuable (ex post) industry oversight, the relevant choice as competition develops is not between regulation and no regulation. Rather, the relevant choice is between extensive ex ante specification of rules and regulations and selective ex post intervention in cases where market competition does not appear to be protecting consumers adequately.

\section{Conclusions.}

The CRRI conferences have been fertile ground for important developments in regulatory economics over the past three decades. These developments include key insights about how to harness competitive forces to motivate incumbent suppliers to serve the best interests of consumers. We have attempted to complement these insights by noting the potential need to motivate regulators to promote efficient competition and discourage inefficient competition. Such need can arise in part because competition can complicate the design of industry policy and limit the ability of regulators to continue to respond as they have historically to the demands of their constituents. Thus, some additional regulation of regulators may be appropriate, just as meaningful oversight of overseers is advisable more generally, as James Madison has observed.

We have noted that once the potential need to motivate regulators is taken into account, standard policy recommendations may require some modification and new policy suggestions may be appropriate. For example, we have suggested the potential merit of antitrust oversight of regulatory sunset provisions as a complement to ongoing judicial review of regulatory decisions. Sunset provisions can require regulators and/or other industry constituents to demonstrate the need for ongoing regulation rather than requiring advocates of deregulation to prove its merits. Federal antitrust oversight may help to limit undue political influence on key regulatory policy decisions. It may also usefully complement judicial oversight by empowering an entity with 
considerable expertise on issues of market power and industry competition to assess whether regulatory actions that are clearly legal serve to promote efficient competition.

We have also emphasized the importance of systematic, ongoing data collection and analysis. Regulators and antitrust authorities alike must have access to consistent, comprehensive, and timely data about industry regulations and performance in order to formulate appropriate policy.

The modifications of standard recommendations and the new recommendations that we have offered are fairly broad in nature. Many important details remain to be considered. For instance, the optimal structuring of sunset provisions merits thorough analysis. Such an analysis should include an examination of the optimal length of time between sunset reviews and the optimal standard of proof required at each review. The political economy of industry oversight in the presence of antitrust review of sunset proceedings also merits further consideration. Antitrust authorities may face increased political pressures as their industry oversight powers and responsibilities increase. ${ }^{48}$ As noted above, this pressure can be reduced by limiting the discretion of antitrust authorities regarding the timing and the nature of the reviews they conduct. Additional policies to insulate the authorities from political pressure may be advisable. ${ }^{49}$

The details of desirable interactions between regulators and antitrust authorities also merit careful consideration, ${ }^{50}$ as do the details of beneficial coordination among regulators, legislators, and judges. ${ }^{51}$ The precise nature of any modification of the Hope standard that is appropriate as industry competition develops also remains to be specified, as does a comprehensive list of the data that regulators should collect and analyze in settings with developing competition. We look forward to future CRRI conferences for guidance on these important issues.

48 Carlton (2007, p. 174) questions "whether regulatory capture is less likely when those who enforce the antitrust law are the same as those who regulate industries."

49 As noted above, the U.S. Department of Justice commissioned a study of the merits of the line-ofbusiness restrictions on the Bell Operating Companies (Huber, 1987). Conceivably, retaining outside experts to direct sunset proceedings could help to insulate antitrust authorities from undue political pressure, particularly if the experts in question have strong reputations for fair and impartial assessments of regulatory matters.

50 Weiser (2009) stresses the need to harmonize the activities of regulatory and antitrust agencies and emphasizes the role that regulators can play in enforcing the remedies that antitrust agencies impose in merger reviews.

51 Ginsburg (2009) suggests changes to judicial review of regulatory rulings that may be appropriate in the presence of "synthetic" industry competition. 


\section{References}

Antitrust Modernization Commission. (2007). Report and recommendations. Washington D.C.

Armstrong, M. (2001). Access pricing, bypass, and universal service, American Economic Review, 91(2), 297-301.

Armstrong, M. (2002). The theory of access pricing and interconnection, in M. Cave, S. Majumdar, and I. Vogelsang (eds.), Handbook of telecommunications economics, Volume I. Amsterdam: North Holland, pp. 295-384.

Armstrong, M. \& D. Sappington. (2006). Regulation, competition, and liberalization, Journal of Economic Literature, 44(2), 325-366.

Armstrong, M. \& D. Sappington. (2007). Recent developments in the theory of regulation, in M. Armstrong \& R. Porter (eds.), Handbook of industrial organization, Volume 3. Amsterdam: North-Holland, pp. 1557-1700.

Avenali, A., G. Matteucci \& P. Reverberi. (2010). Dynamic access pricing and investment in alternative infrastructures, International Journal of Industrial Organization, 28(2), 167-175.

Baker, J. (2003). The case for antitrust enforcement, Journal of Economic Perspectives, 17(4), 27-50.

Baumol, W. (1979). Quasi-permanence of price reductions: A policy for prevention of predatory pricing, Yale Law Journal, 89(1), 1-26.

Baumol, W. \& J. G. Sidak. (1994). Toward competition in local telephony. Cambridge MA: The MIT Press and Washington D.C.: The American Enterprise Institute.

Baumol, W. \& A. Walton. (1973). Full costing, competition and regulatory practice, Yale Law Journal, 82(4), 639-655.

Brennan, T. (2008). Skating toward deregulation: Canadian developments, Federal Communications Law Journal, 60(2), 335-368.

Brock, G. (1994). Telecommunications policy for the information age. Cambridge, MA: Harvard University Press.

Cambini, C. \& Y. Jiang. (2009). Broadband investment and regulation: A literature review, Telecommunications Policy, 33(10-11), 559-574.

Canadian Radio-television and Telecommunications Commission (CRTC). (1997). Telecom Decision CRTC 97-8. 
CRTC. (2005). Forbearance from regulation of local exchange services, Telecom Public Notice CRTC 2005-2, Evidence of the Commissioner of Competition, June 22.

CRTC. (2007a). Review of regulatory framework for wholesale services and definition of essential service, Telecom Public Notice CRTC 2006-14, Evidence of the Commissioner of Competition, March 15.

CRTC. (2007b). Review of regulatory framework for wholesale services and definition of essential service, Telecom Public Notice CRTC 2006-14, Supplementary Material of the Commissioner of Competition, July 5.

Carlton, D. (2007). Does antitrust need to be modernized? Journal of Economic Perspectives, 21(3), 155-176.

Chevron U.S.A. Inc. v. Natural Resources Defense Council, Inc. (1984). 467 U.S. 837.

Colorado Revised Statutes. (2008). 40-15-501. Legislative declaration - purpose and scope of part. C.R.S. 40-15-501.

Crandall, R. (1989). The role of the U.S. local operating companies, in R. Crandall \& K. Flamm (eds.), Changing the Rules: Technological Change, International Competition, and Regulation in Telecommunications. Washington D.C.: The Brookings Institution, pp. 114-146.

Crandall, R. and L. Waverman, (1995). Talk is cheap. Washington D.C.: The Brookings Institution.

Crew, M. \& P. Kleindorfer. (1996). Incentive regulation in the United Kingdom and the United States: Some lessons, Journal of Regulatory Economics, 9(3), 211-225.

Crew, M. \& P. Kleindorfer. (2002). Regulatory economics: Twenty years of progress? Journal of Regulatory Economics, 21(1), 5-22.

Crew, M. \& P. Kleindorfer. (2011). Handbook of worldwide postal reform. Cheltenham, UK: Edward Elgar.

DeGraba, P. (1987). The effects of price restrictions on competition between national and local firms, RAND Journal of Economics, 18(3), 333-347.

de Butts, J. (1973). An unusual obligation. Speech before the National Association of Regulatory Utility Commissioners, Seattle, Washington, September 20.

Duquesne Light Co. v. Barasch. (1989). 488 U.S. 299.

Easterbrook, F. (1984). The limits of antitrust, Texas Law Review, 63(1), 1-40. 
Federal Communications Commission (FCC). (2005). In the matter of unbundled access to network elements, Review of the section 251 unbundling obligations of incumbent local exchange carriers, WC Docket No. 04-313, CC Docket No. 01-338, Order On Remand, Released February 4.

FCC. (2009). In the matter of consumer information and disclosure truth-in-billing and billing format IP-enabled services. Notice of Inquiry, CG Docket No. 09-158, Released August 28.

Federal Power Commission v. Hope Natural Gas Co. (1944). 320 U.S. 591, 603, 605.

Gifford, R. (2003). Regulatory impressionism: What regulators can and cannot do, Review of Network Economics, 2(4), 466-479.

Ginsburg, D. (2009). Synthetic competition, in F. Leveque and H. Shelanski (eds.), Antitrust and regulation in the EU and US. Edward Elgar: Cheltenham, UK, pp. 1-19.

Goldberg, V. (1976). Regulation and administered contracts, Bell Journal of Economics and Management Science, 7(2), 426-447.

Grajek, M. \& L. H. Röller. (2011). Regulation and investment in network industries: Evidence from European telecoms, Journal of Law and Economics, (forthcoming).

Hamilton, A., J. Jay, \& J. Madison. (1961). The federalist papers. New York: New American Library.

Hausman, J. (1997). Valuing the effect of regulation on new services in telecommunications, Brookings Papers on Economic Activity: Microeconomics, Brookings Institution, pp. 1-38.

Hausman, J. (2003). Regulated costs and prices in telecommunications, in G. Madden (ed.), International handbook of telecommunications economics, Volume 2: Emerging telecommunications networks. Edward Elgar Publishers, Cheltenham, UK, pp. 199-233.

Hausman, J. \& J. G. Sidak. (2007). Evaluating market power using competitive benchmark prices instead of the Herfindahl-Hirschman index, Antitrust Law Journal, 74(2), 387-407.

Hazlett, T. (2006). Rivalrous telecommunications networks with and without network sharing, Federal Communications Law Journal, 58(3), 477-509.

Hazlett, T. \& A. Caliskan. (2008). Natural experiments in broadband regulation, Review of Network Economics, 7(4), 460-80.

Huber, Peter. (1987). The geodesic network: 1987 report on competition in the telephone industry. Washington, D.C.: The U. S. Department of Justice.

Industry Canada. (2007). Order varying telecom decision 2006-15, Canada Gazette 141, April 18, available at http://canadagazette.gc.ca/partII/2007/20070418/html/sor71-e.html. 
Kahn, A. (1970). The economics of regulation: Principles and institutions. Vol. I, New York: John Wiley and Sons.

Kahn, A. (1984). The uneasy marriage of regulation and competition, Telematics, 1(5), 1-17.

Kahn, A. (1990). Deregulation: Looking backward and looking forward, Yale Journal on Regulation, 7(2), 325-354.

Kahn, A. (1999). Bribing customers to leave and calling it competition, The Electricity Journal, 12(4), 88-90.

Keeler, T. (1983). Railroads, freight and public policy. Washington D.C.: The Brookings Institution.

Lehman, D. \& D. Weisman. (2000a). The telecommunications act of 1996: The "costs" of managed competition. Kluwer Academic Publishers: Norwell, MA.

Lehman, D. \& D. Weisman. (2000b). The political economy of price cap regulation, Review of Industrial Organization, 16(4), 343-356.

Levine, M. (1965). Is regulation necessary? California air transportation and national regulatory policy, Yale Law Journal, 74(8), 1416-1447.

Levine, M. (1987). Airline competition in deregulated markets: Theory, firm strategy, and public policy, Yale Journal on Regulation, 4(2), 393-494.

Littlechild, S. (2003). Reflections on incentive regulation, Review of Network Economics, 2(4), 289-315.

Market Street Railway Co. vs. Railroad Commission of California. (1945). 324 U.S. 548.

McChesney, F. (1997). Money for nothing: Politicians, rent extraction, and political extortion. Cambridge MA: Harvard University Press.

McChesney, F. \& W. Shughart. (1995). The causes and consequences of antitrust: The publicchoice perspective. Chicago: University of Chicago Press.

OFCOM. (2006). Retail price controls: Explanatory statement. July 19, available at http:// stakeholders.ofcom.org.uk/binaries/consultations/retail/statement/rpcstatement.pdf.

OFTEL. (2003). Review of fixed narrowband retail markets. March 17, available at http://www. ofcom.org.uk/static/archive/oftel/publications/eu_directives/2003/eu_retail/retail_3.htm.

Peltzman, S. (1976). Toward a more general theory of regulation, Journal of Law and Economics, 19(2), 211-240. 
Posner, R. (1971). Taxation by regulation, Bell Journal of Economics, 2(1), 22-50.

Posner, R. (1975). The social costs of monopoly and regulation, Journal of Political Economy, 83(4), 807-827.

Posner, R. (2001). Antitrust law, Chicago: The University of Chicago Press.

Robinson, G. \& D. Weisman. (2008). Designing competition policy for telecommunications, Review of Network Economics, 7(4), 509-546.

Sappington, D. (2002). Price regulation, in M. Cave, S. Majumdar \& I. Vogelsang (eds.), The handbook of telecommunications economics. Volume I: Structure, regulation, and competition. Elsevier Science Publishers, pp. 225-293.

Sappington, D. \& D. Weisman. (1996a). Designing incentive regulation for the telecommunications industry. Cambridge MA.: MIT Press and Washington D.C.: AEI Press.

Sappington, D. \& D. Weisman. (1996b). Revenue sharing in incentive regulation plans, Information Economics and Policy, 8(3), 229-248.

Sappington, D. \& D. Weisman. (2010). Price cap regulation: What have we learned from twentyfive years of experience in the telecommunications industry? Journal of Regulatory Economics, 38(3), 227-257.

Sidak, J. G. \& D. Spulber. (1997). Deregulatory takings and the regulatory contract. Cambridge, MA: Cambridge University Press.

Stigler, G. (1971). The theory of economic regulation, Bell Journal of Economics, 2(1), 3-21.

Tardiff, T. \& W. Taylor. (2003). Aligning price regulation with telecommunications competition, Review of Network Economics, 2(4), 338-354.

Telecommunications Act of 1996. (1996). Preamble, Pub. L. No. 104-104, 110 Stat. 56 (codified as amended in scattered sections of 47 U.S.C.)

United States Department of Justice (USDOJ). (2010). In the matter of economic issues in broadband competition: A national broadband plan for our future, Ex Parte Submission Before the Federal Communications Commission, GN Docket No. 09-51, January 4.

Verizon Communications Inc. v. FCC. (2002). 535 U.S. 467.

Vogelsang, I. (2002). Incentive regulation and competition in public utility markets: A 20-year perspective, Journal of Regulatory Economics, 22(1), 5-27. 
Weiser, P. (2009). Rethinking merger remedies: Toward a harmonization of regulatory oversight with antitrust merger review, in F. Leveque \& H. Shelanski (eds.), Antitrust and Regulation in the EU and US. Edward Elgar: Cheltenham, UK, pp. 128-159.

Weisman, D. (1988). Default capacity tariffs: Smoothing the transitional regulatory asymmetries in the telecommunications market, Yale Journal on Regulation, 5(1), 149-178.

Weisman, D. (2002). Is there 'hope' for price cap regulation? Information Economics and Policy, 14(3), 349-370.

Weisman, D. (2006). When can regulation defer to competition for constraining market power?: Complements and critical elasticities, Journal of Competition Law \& Economics, 2(1), 101-112.

Weisman, D. \& G. Robinson. (2009). Lessons for modern regulators from Hippocrates, Schumpeter and Kahn, in R. May (ed.), New Directions in Communications Policy. Durham, NC: Carolina Academic Press, pp. 3-37. 